\title{
Pollen Atlas of the Flora of Egypt. 2. Species of Polygonaceae*
}

\author{
Salah M. El Naggar \\ Botany Department, Faculty of Science, \\ Assiut University.
}

and

Nahed El-Husseini

The Herbarium - Botany Department, Faculty of Science, Cairo University, Giza, Egypt.

El-Naggar, S. M. \& El-Husseini, N. 2001. Pollen Atlas of the Flora of Egypt. 2. Species of Polygonaceae. Taeckholmia 21(1):143-151.

Pollen grains of 20 species belonging to 7 genera of Polygonaceae represented in the Flora were studied using Light and Scanning Electron Microscope. Pollen characters, including those of size, shape, exine sculpture and structure of the aperture allowed the recognition of five pollen types: Atraphaxixs, Calligonum-Oxygonum, Persicaria, Polygonum and Rumex-Emex types. A key for the seperation of the different types is provided and the pollen morphology in relation to taxonomy of the investigated taxa is briefly discussed.

Key words: Flora of Egypt, Pollen atlas, Polygonaceae.

\section{Introduction}

Polygonaceae is a well-defined cosmopolitan family containing more than 40 genera and 300 species of herbs, shrubs and trees; mainly known from the north temperate regions.

The classification of Polygonaceae has remained a major challenge for taxonomists at the generic and tribal levels (Meissener, 1857; Gross, 1913; Jaretzky, 1928; Hedberg, 1946; Graham \& Wood, 1964; Roberry \& Vautier, 1964; Hara, 1966; Haraldson, 1978 and Ronse-Decraene, 1988). The early classifications of the Polygonaceae were based mainly on gross morphological characters (Meissener, 1826; Bentham and Hooker, 1880). Recently, other criteria have been used in the classification of this family including anatomy (Vautier, 1949; Haraldson, 1978), chromosome number (Löve and Löve, 1956), and chemical constituents (Jaretzky, 1928).

According to Täckholm (1974: 58-68) Polygonaceae is represented by 28 species. A less number of 24-26 species which belong to seven-eight genera were reported by El-Hadidi (1997:24-26) and Boulos (1999:21-34); while El-Husseini and ElHadidi (2000: 64-82) reported the presence of seven genera and 24 species.

\footnotetext{
* Continued from Täckholmia 20(2):173-179.
} 
Table (1): Collection data of the investigated taxa.

\begin{tabular}{|c|c|c|}
\hline Code number & Species & Locality \\
\hline 19.22 .45 & Atraphaxis spinosa & $\begin{array}{l}\text { On the step way to Gebel Musa, Sinai, 10.5.1965; El-Hadidi (CAI) } \\
\text { - Gebl Catherine, Sinai, April 1940; M. Hassib (CAI). }\end{array}$ \\
\hline 19.23.46 & Calligonum comosum & $\begin{array}{l}\text { Bahariya depression, } 65 \mathrm{~km} \mathrm{~s} \text {. Bawiti, 23.3.1968; Romée (CAI) - } \\
\text { Alexandria desert road, } 4-7 \mathrm{~km} \text { from pyramids, 26.12.1952; Boulos } \\
\text { (CAI) - Cairo - Assiut desert road, } 30 \mathrm{~km} \text { S. Assiut, 30.3.1998; El- } \\
\text { Naggar (AST). }\end{array}$ \\
\hline 19.24.47 & Emex spinosus & $\begin{array}{l}\text { In the fields around Iking Mariut, 7.4.1967; V. Täckhholm et al. } \\
\text { (CAI) - El-Minia, in the fields, 22.3.1998; El-Naggar (AST). }\end{array}$ \\
\hline 19.25 .48 & Oxygonum sinuatum & $\begin{array}{l}\text { Gebel Elba, January } 14^{\text {th }} \text { Feb. } 6^{\text {th }} 1933 \text {; Fahmy \& Hassib (CAI) }- \\
\text { Gebl Elba, January 23-27 } 1929 \text {; G. Täckholm (CAI). }\end{array}$ \\
\hline 19.25 .51 & Polygonum plebeium & $\begin{array}{l}\text { El-Minia, 15.10.1971; Boulos et al. (CAI), Arab Mutaer, } \\
\text { 10.1.1998; El-Naggar (AST). }\end{array}$ \\
\hline 19.26 .54 & P. patulun & $\begin{array}{l}\text { Tahrir province, 8.6.1973; Ibrahim et al. (CAI) - Dakhla Oasis, } \\
\text { 2.5.1969; Osborn \& Helmy. }\end{array}$ \\
\hline 19.26.55 & P. equisetiforme & $\begin{array}{l}\text { Sallum town, 24.5.1963; V. Täckholm et al. (CAI) - } 120 \mathrm{~km} \text { west } \\
\text { of Mersa Matruh, 28.9.1963; Boulos (CAI). }\end{array}$ \\
\hline 19.27.56 & Persicaria lapathifolia & $\begin{array}{l}\text { El-Mallawi, 18.10.1971; Boulos et al. (CAI) - Mahmoudia, Miniet } \\
\text { El Sdid, 14.8.1970; Imam et al. (CAI). }\end{array}$ \\
\hline 19.27.57 & P. decipiens & $\begin{array}{l}\text { Ras El Barr, 2.7.1976; El Gazzar et al. (CAI) - Along the canals at } \\
\text { Masraf El Gosh, N. Inshas, 28.8.1959; V. Täckholm (CAI). }\end{array}$ \\
\hline 19.27.58 & P. senegalensis & $\begin{array}{l}\text { On the way to Beilbeis along Ismailia canal, 27.3.1968; V. } \\
\text { Täckholm et al. (CAI) - Sendabis, Al-Qanater El-Khairia, } \\
\text { 18.8.1971; Imam et al. (CAI). }\end{array}$ \\
\hline 19.27.59 & P. lanigera & Assiut, El-Salakhana, 10.3.1983; Zareh (AST). \\
\hline 19.27.60 & P. attenuata & $\begin{array}{l}\text { Faraskur, 27.10.1967; V. Täckholm et al. (CAI) - Between Ras El } \\
\text { Bar and Damietta, 13.9.1929; Hefnawy (CAI). }\end{array}$ \\
\hline 19.28.61 & Rumex pictus & $\begin{array}{l}\text { Rosetta, 20.4.1973; Ibrahim et al. (CAI) - Sidi Abdel Rahman, } \\
\text { 8.3.1978; Soliman (CAI). }\end{array}$ \\
\hline 19.28.62 & R. cyprius & $\begin{array}{l}\text { Wadi Aber, Gebl Ataqa, Suez road, 8.4.1967; V. Täckholm (CAI) - } \\
\text { Wadi along } 60 \text { km S. of Suez, 25.2.1964; Kassas (CAI). }\end{array}$ \\
\hline 19.28.63 & R. vesicarius & $\begin{array}{l}\text { Wadi Angabya, Suez road, 23.1.1956; El-Hadidi (CAI) - Burg El- } \\
\text { Arab, 1.4.1960; El-Batanony (CAI). }\end{array}$ \\
\hline 19.28.64 & R. simplicif lorus & $\begin{array}{l}\text { Gebel Hamata, Red Sea Coast, 7.2.1961; V.Täckholm (CAI) - } \\
\text { Khor Wadi Yahameib, Gebl Elba, 22.1.1962; V. Täckholm et al. } \\
\text { (CAI). }\end{array}$ \\
\hline 19.28.66 & R. crispus & Shebin Al-Qanatir, Arab El Hosne, 18.6.1983; El-Fayoumi (CAI). \\
\hline 19.28.67 & R. pulcher & $\begin{array}{l}\text { Kobry El Serafy, Idfina - Alexandria road, 16.3.1984; El-Garf \& } \\
\text { El-Fayoumi (CAI). }\end{array}$ \\
\hline 19.28 .68 & R. dentatus & $\begin{array}{l}\text { Fayium, stop at a field, 12.2.1952; El-Hadidi (CAI) - El-Minia, in } \\
\text { the fields, 22.3.1998; El Naggar (AST). }\end{array}$ \\
\hline
\end{tabular}


Polygonaceae is considered to be one of the europalynous families among the dicotyledons (Wodehouse, 1931; Erdtman, 1960). Its pollen morphology and taxonomy has been the subject of several studies among which may be mentioned: Gross (1913), Wodehouse (1931), Hedberg (1946), Erdtman (1960), Nowicke and Skvarla (1977) and Van Leeuwen et al. (1988).

The present account deals with the pollen morphology of 20 species belonging to seven genera of Polygonaceae. It aims to asses the significance of the pollen characters in the species delimitation.

\section{Material and Methods}

This study is based on mature pollen grains of 20 species of the Polygonaceae (ElHusseini \& El-Hadidi: 64-82, 2000). The code number preceeding each species is that used for the computer data base of the Vascular plants represented in the Flora of Egypt. Samples of pollen grains of each species were collected from their natural habitats as shown in Table (1) or from herbarium specimens. Voucher specimens for each studied species are kept in the herbarium of Cairo University (CAI, Holmgren et al. 1990) and the herbarium of Botany Department, Faculty of Science, Assiut University (AST, proposed abbreviation).

Materials for light microscopy were boiled for about 30 seconds in an aquous 5\% $\mathrm{NaOH}$, washed several times with distilled water, spread on a clean slide in a drop of lactic acid and gently heated until the boiling point. The pollen grains were examined using a Nikon 140 Research microscope.

Materials for SEM were prepared by mounting acetolyzed pollen grains onto clean stubs using double sided cellotape. Untreated dry pollen grains were mounted directly onto other stubs. Some acetolyzed pollen grains were mounted onto clean stubs and with clean cover slips were forced against to fractionate them to study the wall. Some others were immersed in liquid nitrogen to frozen and then ruptured with hammer. These stubs were coated with gold in a JE0l JFC 1100 Eion. sputtering device. Pollen grains were then examined in a JE0L JSM 5400 LV Scanning Electron Microscope operated at accelerated voltage of $15 \mathrm{KV}$., at Electron Microscopy Unit, Assiut University. The terminology used here for pollen description followed Erdtman (1952) and Ristima (1970).

\section{Results}

Table (2) presents the pollen morphological features of the investigated species; belonging to five pollen types that can be distinguished through the following key:

1.a. Pollen grains pantopolyporate ...................................... Persicaria type

b. Pollen grains $3-4$ - colporate ...................................................... 2

2.a. Pollen grains oblate - spheroidal .............................. Rumex-Emex type

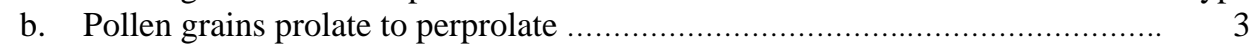

3.a. Tectum scabrate granulate or microechinate ....................... Polygonum type

b. Tectum foveolate - reticulate or striate - reticulate .............................. 4

4.a. Tectum striate - reticulate ................................................ Atraphaxis type

b. Tectum foveolate - microreticulate .................. Calligonum - Oxygonum type 
Table (2). Summary of palynological data of the investigated taxa, all measurments in $\mu \mathrm{m}$.

\begin{tabular}{|c|c|c|c|c|c|c|c|}
\hline \multirow{2}{*}{ Number } & \multirow{2}{*}{ Species } & \multicolumn{3}{|c|}{ Dimensions } & \multirow{2}{*}{ Shape } & \multirow{2}{*}{$\begin{array}{l}\text { Aperture } \\
\text { characters }\end{array}$} & \multirow{2}{*}{ Exine sculpture } \\
\hline & & $\mathbf{P}$ & $\mathbf{E}$ & $\mathbf{P} / \mathbf{E}$ & & & \\
\hline 19.22 .45 & Atraphaxis spinosa & $30-35$ & $25-27$ & 1.25 & prolate & Tricolporate & striate - reticulate \\
\hline 19.23.46 & Calligonum comosum & $27-35$ & $22-30$ & 1.19 & prolate & Tricolporate & reticulate - microreticulate \\
\hline 19.24.47 & Emex spinosa & $20-26$ & $20-26$ & 1 & spheroidal & Tricolporate & microreticulate - foveolate \\
\hline 19.25.48 & Oxygonum sinuatum & $47-50$ & $35-40$ & 1.30 & prolate & Tricolporate & reticulate - microreticulate \\
\hline 19.26.51 & Polygonum plebeium & $25-27.5$ & $20-25$ & 1.16 & prolate & Tricolporate & scabrate punctate \\
\hline 19.26.54 & P. patulun & $20-25$ & $15-20$ & 1.30 & prolate & Tricolporate & scabrate punctate \\
\hline 19.26 .55 & P. equisetiforme & $22.5-30$ & $15-20$ & 1.50 & prolate & Tricolporate & scabrate punctate \\
\hline 19.27.56 & Persicaria lapathifolia & 42.5 & 42.5 & 1 & spheroidal & Pantoporate & coarse reticulate \\
\hline 19.27.57 & P. decipiens & $47.5-52.5$ & $47.5-52.5$ & 1 & spheroidal & Pantoporate & coarse reticulate \\
\hline 19.27.58 & P. senegalensis & $40-50$ & $40-50$ & 1 & spheroidal & Pantoporate & coarse reticulate \\
\hline 19.27.59 & P. lanigera & $32.5-37.5$ & $32.5-37.5$ & 1 & spheroidal & Pantoporate & coarse reticulate \\
\hline 19.27.60 & P. attenuata & $48.5-56.5$ & $48.5-56.5$ & 1 & spheroidal & Pantoporate & coarse reticulate \\
\hline 19.28.61 & Rumex pictus & $20-25$ & $20-25$ & 1 & spheroidal & Tricolporate & microreticulate - foveolate \\
\hline 19.28.62 & R. cyprius & $25-27.5$ & $25-27.5$ & 1 & spheroidal & Tricolporate & microreticulate - foveolate \\
\hline 19.28.63 & R. vesicarius & $22.5-25$ & $22.5-25$ & 1 & spheroidal & Tricolporate & microreticulate - foveolate \\
\hline 19.28.64 & R. simpliciflorus & $20-27$ & $20-27$ & 1 & spheroidal & Tricolporate & microreticulate - foveolate \\
\hline 19.28.66 & R. crispus & $22.5-25$ & $22.5-25$ & 1 & spheroidal & Tricolporate & microreticulate - foveolate \\
\hline 19.28.67 & R. pulcher & $27.5-32.5$ & $27.5-32.5$ & 1 & spheroidal & Tricolporate & microreticulate - foveolate \\
\hline 19.28 .68 & R. dentatus & $20-25$ & $20-25$ & 1 & spheroidal & Tricolporate & microreticulate - foveolate \\
\hline
\end{tabular}

\section{1- Atraphaxis type}

Pollen grains isopolar, radiosymmetric, tricolpate or tricolporate, $30-35$ x $25-27$ um, prolate, striate-reticulate. Aperture: ectoaperture colpus long, slit-like, wide, distinctly sunken, margins distinct, ends acute to obtuse; endoaperture \pm porus. Exine thick, nexine thinner than sexine, sexine 1- columellate, columella indistinct; sexine 2- tectate, tectum foveolate with holes of different shape and size. Exine ornamentation composed of narrow ridges (muri), connected with each other in different ways and foveolate furrows (lumina); ridges and furrows running parallel to the colpus.

This pollen type characterizes Atraphaxis spinosa (Fig. 1a). 


\section{2- Calligonum - Oxygonum type}

Pollen isopolar, radiosymmetric, tricolpate, 27-35 x 22-30 $\mu \mathrm{m}$ (Calligonum) 47-50 x 35$40 \mu \mathrm{m}$ (Oxygonum), prolate to spheroid, reticulate to microreticulate. Aperture ectoaperture colpus, narrow, slit-like, long or very long (94\% of the equatorial axis), sunken, margins distinct, irregular, ends acute, endoaperture colpus or porus, elongated, lalongate, sometimes slightly rhombic, margins distinct. Exine thick, sexine thicker than nexine, sexine one columellate, sexine two tectat semitectate, tectum reticulate, mural areas visible which represent fused apices of columella, lumina variable in outline \pm elongate or circular.

This type characterizes two species: Calligonum comosum L' Her. and Oxygonum sinuatum (Hochst. \& Steud.) Dammer (Fig. 1b).

\section{3- Rumex - Emex type}

Pollen isopolar, radiosymmetric 3-4-colporate, 22-32 x 22-32 $\mu \mathrm{m}$ (Rumex) 20-26 x 20-26 $\mu \mathrm{m}$ (Emex), oblate to spheroid, microreticulate-foveolate. Aperture, ectoaperture colpus, narrow, slit like, long or very long ( $90 \%$ of the polar axis), usually sunken sometimes not or only slightly sunken, margin distinct, irregular, ends acute, endoaperture porus, circular, slightly lalongate or \pm lolongate. Exine thick, sexine thicker than nexine, sexine one columellate, columella low either distinct or indistinct, uniform in thickness, sexine two tectate, sexine three scabrate; muri simple columellate, often irregular in surface view, always beset with granular scabrate, lumina irregular in outline, usually \pm circular, sometimes indistinct columellae circular in cross section.

Emex spinosus (L.) Campdera, Rumex pictus Forssk., R. cyprius Murb., R. vesicarius L., R. simpliciflorus Murb., R. crispus L., R. pulcher L. and R. dentatus (Fig. 1c).

\section{4- Persicaria type}

Pollen isopolar, radiosymmetric, pantoporate, 32-50 x 33-55 $\mu \mathrm{m}$, oblate-spheroid; coarse reticulate. Aperture, ectoaperture porus circular, situated in a single lumen of the reticulum, not sunken, margins not particularly distinct, number of pori 12-27, endoaperture porus, distinct, irregular, exine thick, sexine much thicker than nexine, sexine one columellate in muri of reticulum and of spherical elements inside lumina, sexine two semitectate. Muri thin duplicolum-ellate, columellae usually opposite or some alternate, lumina variable in size, angular, usually forming 4-6 sided polygonal the side straight in fully expanded grains, slightly wavy in contracted grains, granules numerous inside lumina.

Persicaria lapathifolia (L.) S.F. Gray, P. decipiens (R.Br.) K.L. Wilson, P. senegalensis (Meisn.) Soják, P. lanigera (R.Br.) Soják and P. attenuata (R.Br.) Soják (Fig. 1d). 


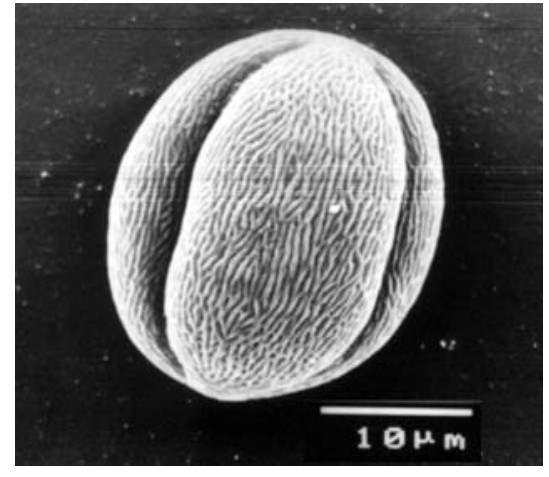

$\mathbf{a}$

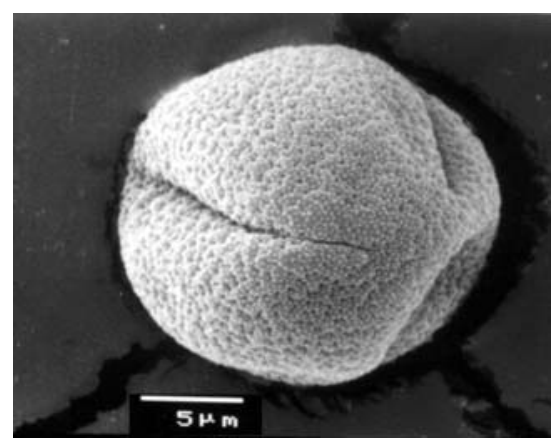

C

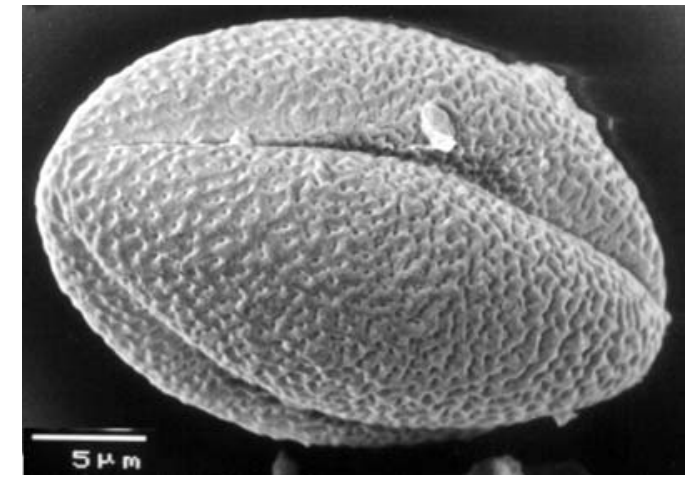

b

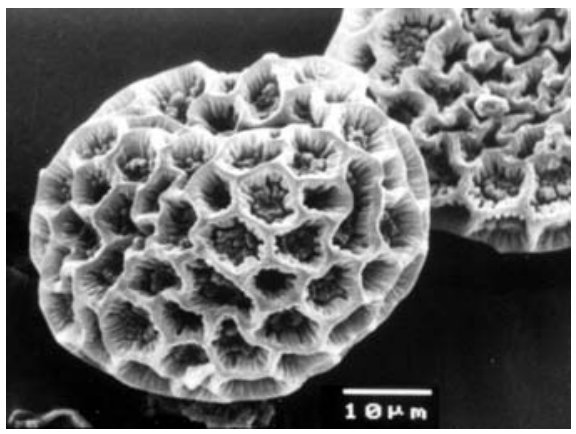

d

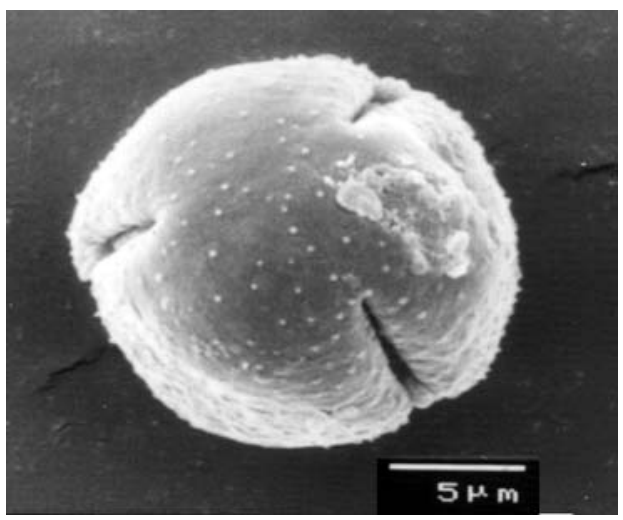

e

Fig. 1. SEM micrographs of pollen grains belonging to the five pollen types, bar $=5$ or $10 \mu \mathrm{m}$. a. Atraphaxis type, e.g. Atraphaxis spinosa, b. Calligonum Oxygonum type, e.g. Calligonum comosum, c. Rumex-Emex type, e.g. Rumex vesicarius, d. Persicaria type, e.g. Persicaria lapathifolia. 


\section{5- Polygonum type}

Pollen isopolar, radiosymmetric, tricolporate, 22-30 x 15-20 $\mu \mathrm{m}$, prolate, rectangular shaped, scabrate, or microechinate. Aperture, endoaperture colpus, long, slit-like, distinctly sunken, margins distinct, irregular, ends acute to slightly obtuse, endoaperture colpus lalongate, exine thick $(1.2 \mu \mathrm{m})$, nexine much thinner than sexine, sexine one columellate, distinct, variable in length, much thicker at the base, sexine two tectate, sexine three scabrate microgranulate or microspinate.

This type characterizes species: Polygonum plebeium R. Br., P. patulum M. Bieb. and P. equisetiforme Sm. (Fig. 1e).

\section{Discussion}

Polygonaceae is an europalynous family (Hedberg, 1946; Erdtman, 1960). Its pollen morphological characters have been successfully used in the classification of the family particularly at the generic level (Gross, 1913; Nowick and Skvarla, 1977; Van Leeuwen et al., 1988).

The present results show that pollen shape, size and aperture characters as well as exine structure and sculpture are reliable to differentiate between the studied taxa.

Pollen shape varies greatly among the studied taxa but it is constant at the generic level. It ranges from oblate to oblate - spheroidal in Rumex, Emex and Persicaria, to prolate - spheroidal and prolate in Oxygonum, Calligonum and Atraphaxis (Table 2). Among the prolate pollen grains of the investigated taxa, the polar area can be used to differentiate between Oxygonum and Polygonum (with broad pole) as well as Atraphaxis and Calligonum (with narrow pole).

Pollen size is also variable among the studied taxa at the generic and specific levels. The smallest pollen grains recorded were in Emex, Rumex and Polygonum and ranged between $23 \times 23 \mu \mathrm{m}$ and $30 \times 25 \mu \mathrm{m}$, the largest pollen grains are those of Oxygonum and Persicaria, 48.5 x $37.5 \mu \mathrm{m}$ and 42.5 x $42.5 \mu \mathrm{m}$ respectively.

Among the examined taxa, apertures are porate or colporate. Porate apertures are usually ectoaperturate and characteristic to Persicaria species. Colpate apertures are endoaperturate and are characteristic to the species of other genera. The apertures vary in their number, position and structure among the studied taxa: these are 12-27 apertures in Persicaria or 3-4 apertures in the other taxa. Colpus length ranges from 66-85 \% of the total polar length in Oxygonum and Polygonum to more than $95 \%$ in Atraphaxis, Calligonum, Rumex and Emex. Apertures are rectangular in Polygonum, Atraphaxis and Calligonum or more or less circular in Rumex and Emex. Ectoaperturute opening are usually circular among the studied taxa of Persicaria.

Exine usually consists of sexine and nexine. Sexine can be differentiated into three layers: sexine one (Columella), sexine two (tectum or semitectum) and sometimes sexine three (microgemmae or microechinae). This stratifiation is clear in Emex, Rumex, Polygonum (Fig. 2a) and Persicaria but indistinct in Calligonum, Oxygonum and Atraphaxis.

Tectum is coarse reticulate in Persicaria, perforate to microreticulate in Rumex and Emex, reticulate in Calligonum and Oxygonum. This is striate - reticulate in Atraphaxis. Sexine three in Polygonum is microgemmae or microgranulae (Fig. 2 b-e). 


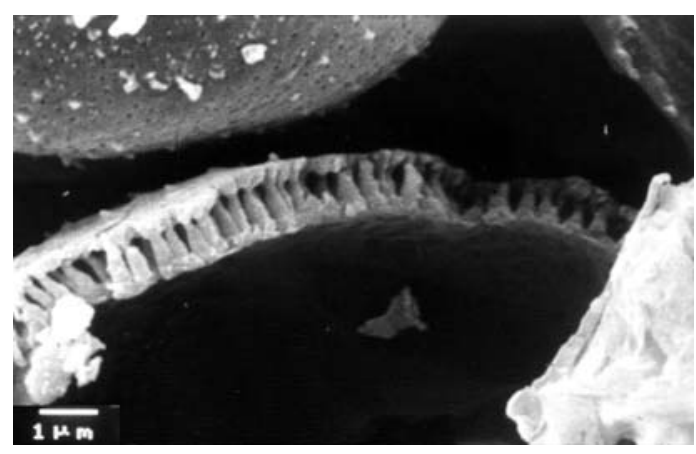

a

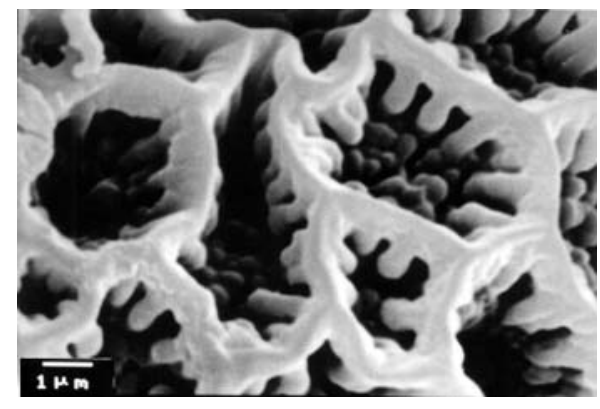

b

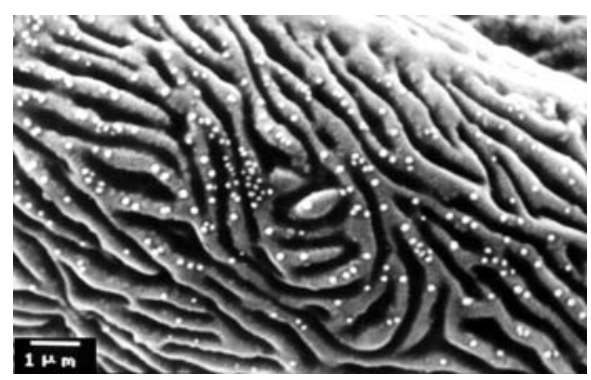

d

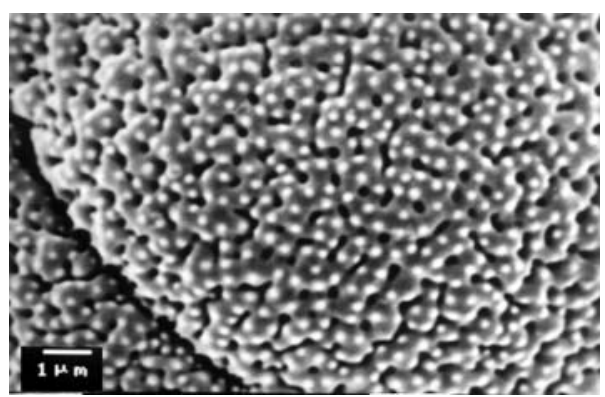

C

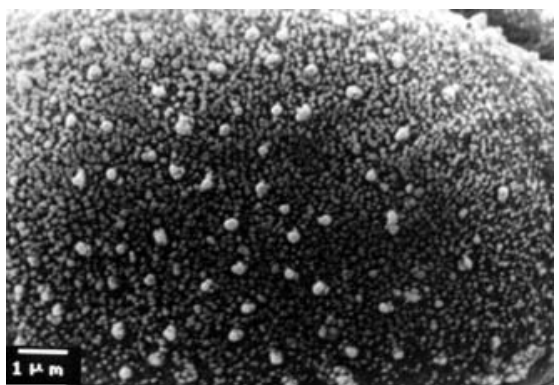

e

Fig. 2. SEM micrographs showing stratification and sculpture among the studied pollen types, bar = $1 \mu \mathrm{m}$.

a. Stratification in sexine of Polygonum patulum (i. columella, ii. tectum, iii. microgemmae), b. Sculpture coarse reticulate, e.g. Prasicaria lapathifolia, c. Sculpture perforate-microreticulate, e.g. Rumex vesicarius, d. Sculpture striate-reticulate, e.g. Atraphaxis spinosa, e. Sculpture microgemmate-microgranulate, e.g. Polygonum patulum. 


\section{References:}

Bentham, G. \& Hooker, J. D. 1880. Genera plantarum, 3(1). London.

Boulos, L. 1999. Flora of Egypt, Vol. 1. Azollaceae - Oxalidaceae. Al Hadara Publishing, Cairo.

El-Hadidi, M. N. 1997. A revised list for the species of Flora Aegyptiaca. Vol. 1 (1998). Taeckholmia 17: 21-32.

El-Husseini, N. \& El-Hadidi, M. N. 2000. Polygonaceae in M. N. El-Hadidi (ed.) Flora Aegyptiaca. 1,2. Palm Press \& Cairo University Herbarium.

Erdtman, G. 1952. Pollen Morphology and Plant Taxonomy. Angiosperms. Almqrist and Wiksell, Stockholm.

1960. The acetolysis method: A revised description. Svensk Bot. Tidskr. 54: 561-564.

Graham, S. A. \& Wood, C. E. 1964. The genera of Polygonaceae in the South Eastern united States. Jour. of the Arnold Arboretum, 46: 91-121

Gross, H. 1913. Remarques sur les polygonaceous de 1' Asie Orientale. Bull. Geog. Bot. 23: 7-32.

Hara, H. 1966. The Flora of Eastern Himalaya, $1^{\text {st }}$ ed. Tokyo Press.

Haraldson, K. 1978. Anatomy and Taxonomy in Polygonaceae subfam. Polygonoideae Meissn. emend. Jaretzky. Symb. Bot. Upsal. 22(2): 1-95.

Hedberg, O. 1946. Pollen morphology in the genus Polygonum L. s. lat. and its taxonomical significance. Svensk Bot. Tidsk. 40: 371-404.

Holmgren, P. K.; Holmgren, N. H. \& Barnett, L. C. 1990. Index Herbariorum. Part I. (ed. 8 New York.

Jaretzky, R. 1928. Histologische and karyologische Studien an Polygonaceen, Jahrbucher für Wissenschaftliche Botanik 69: 357-491.

Löve, A. \& Löve, D. 1956. Chromosomes and taxonomy of Eastern North American Polygonum. Canad J. Bot., 34: 501-521.

Meissner, C. F. 1826. Monographiae generis polygoni prodromus. Geneva.

.. 1857. Polygonaceae in A. De Candolle, Systematis Naturalis Regni Vegetabilis, 14. Paris.

Nowicke, J. W. \& Skvarla, J. J. 1977. Pollen morphology and the relationship of the Plumbaginaceae, Polygonaceae and Primulaceae to the order Centrospermae. Smitson. Contrib. Bot. 37: 1-64.

Ristima, T. 1970. Suggestions towards unification of descriptive terminology of angiosperm pollen grains. Rev. palaeobot. Palynol. 10: 39-60.

Roberry, G. \& Vautier, S. 1964. Les genres de polygonacees. Boissiera, 10: 7-129.

Ronse-Decraene, L. P. \& Akeroyd, J. R. 1988. Generic limits in Polygonum and related genera (Polygonaceae) on the basis of floral characters. Bot. J. Linn. Soc. 98: 321-371.

Täckholm, V. 1974. Student's Flora of Egypt ed. 2. Cairo University.

Van Leeuwen, P.; Punt, W. \& Hoen, P. P. 1988. The Northwest European pollen Flora, 43. Polygonaceae. Rev. palaeobot. Palynol. 57: 81-151.

Vautier, S. 1949. La vascularisation florale chez les polygonacees. Candollea, 12: 219343.

Wodehouse, R. P. 1931. Pollen grains in the identification and classification of plants -6 . Polygonaceae. Am. J. Bot. 18: 749-764. 